\title{
Complicating Social Order in the Rural Areas of Akwa Ibom State Nigeria
}

\author{
Moses I. Peters \\ Aniekan E. Bassey \\ Department of Sociology and Anthropology \\ University of Uyo, Uyo, Nigeria
}

\begin{abstract}
In a typical traditional society in Nigeria laws, rules, norms, and taboos were used by community elders to enforce social order and curtail practices, behaviours, values and beliefs that were counter to the stability of the social structure. However, the contemporary rural communities have witnessed a shift within the social structures and institutions, in behaviours, cultural aspects which affect social relations, social interaction and the maintenance of the status quo by the traditional rulers. This qualitative study examined the roles of traditional rulers in complicating social order in Ikot Annang and Ikot Abasi communities in Akwa Ibom State, South-South Nigeria. In-depth interviews and participant observation were used to collect data on the subject under study. Ethnomethodology by Garfinkel was adopted as theoretical guide for the study. Findings of the study show that betrayal of community interest, mismanagement of community generated revenue, neglect of traditions, abuses of traditional power by some community elders, and youth groups are contributing to upheaval in some rural communities in Akwa Ibom State. Researchers concluded that the decisions by some of the rural community elders and youth groups to adopt western customs over their traditional customs have distorted the state of stability and consensus that existed in the traditional rural areas, thereby bringing about a shift that disrupts social order. Among other, the researchers recommended the need for culture check and rite of passage for youth groups in line with customs and traditions.
\end{abstract}

Keywords: Social order, rural area, community elders, youth groups and customs

\section{Introduction}

Social order was an identifiable traditional status of most African communities. It has been known that traditional African societies, indeed, had well organized and well established systems of administration where public order was provided and maintained; where laws were made and implemented; were intercommunal and intertribal conflicts were settled (Itodo and Onodugo, 2016). According to Petkovi (2007), the origin of the word tradition points to the process of transmission, delivery, and maintenance of values, properties, customs, and principles, forms, which mark the cultural identity of individuals, groups, nations, and mankinds. Traditional institutions have been a significant feature of the African people and have commanded a large degree of loyalty and respect among them (Itodo and Onodugo, 2016). According to Abacha (1994) cited in Achebe (2017), traditional rulers are closely linked with the grassroots, and so understand the problems of our people intimately therefore, 
in our search for peace, order and stability in our society, the institution could be a veritable instrument.

Right from the pre-colonial, colonial to post-colonial eras, the traditional institutions in Nigeria are custodians of laws, norms, customs and governance among the people especially in the rural community setting. According to Itodo and Onodugo (2016), the traditional rulers are the paramount authority or natural ruler in any given community. This set of individuals are considered community elders and they constitute the decision making body over their subjects. Osakede and Ijimakinwa (2015) opined that prior to colonization there existed a system of indigenous traditional administration which varied from one part of the country to the other. The Northern part of Nigeria, the Hausa/Fulani practiced a highly centralized system of government where the emir is both the political and religious leader. Fatile and Adejuwon (2010) posit that the Emir had the responsibility of making laws, enforcing them and maintaining peace and order in his emirate. He was also expected as a religious leader to ensure the provisions of Islamic and Sharia laws to guide the conduct of the affairs of the emirate. The Emir had a number of advisers who assisted him in the day-to-day administration of the emirate.

Fatile and Adejuwon (2010) argued that, in the western part of Nigeria, the administrative system was monarchical under the headship of the Oba, who was assisted in the discharge of his duties by Yoruba Baales who administered towns and villages and paid royalties to the Oba at specified times of the year. Fadipe (1970) cited in Osakede and Ijimakinwa (2015) posits that, the Igbo of the Eastern region of Nigeria are republican and egalitarian in nature because generally they have no kings or chiefs. Fadipe stated that "Ohaneze" which comprise of family heads that hold "Ofo" title, as an assembly of elders, were the major executive, legislative and judicial, and administrative officers. According to him, decisions are taken on behalf of the people by this assembly of "Ofo" title holders. This Council of elders is assisted by various Age-Grade organizations that perform general functions. These include the maintenance of law and order, serving as army for the defence of the village against external attack, construction and maintenance of roads, prevention of abuse of powers by the council of elders (Osakede and Ijimdinka, 2015). This traditional setting spread across the South-South region of Nigeria, though with different names ascribed to each assembly of community elders as accepted by the language structure of the people. This traditional structure is still in existence in Akwa Ibom State. In fact, this structure is what defines the community setting in rural areas of the state.

The socio-cultural shift that exit within the traditional institutions and the social structure of their communities in Africa underlies the question of what are the causes of this shift and the pattern of its flow. In a typical African society as stated by Itodo and Onodugo (2016), the traditional institutions (the community elders) commands a great degree of loyalty and respect from their 


\section{The Nigerian Journal of Sociology and Anthropology Vol. 17 no. 2}

subjects which states the flow of influence of order within the social structure especially in the rural areas. This was discovered by the colonial masters thereafter, the indirect rule system of colonial governance. The flow still remains today, and the orderly nature of these communities remains with the traditional rulers who are considered as the royal elders.

Most of these community elders or traditional rulers today have contact with the Western cultures through Western education, and some of them have tested the Western life abroad. According to Fatile (2010), most of traditional rulers across the country are now modern, more educated and career persons in their chosen field before ascending to the stool of their fore fathers. The influence of this modernized customs exerted consciously or unconsciously by some of these elders on their subjects has brought about a structural shift which affects the entire social structure, thence social order, especially in the rural settings of some communities in Akwa Ibom State, Nigeria.

The sway in which our society has shifted is to an extent a challenge for social and cultural identity, and the structural capacity to withstand the inundating influence of the Western world found within the custodians of traditional authority, and their quest for the maintenance of social order and traditional status quo of the various communities. Some of the rural areas in Akwa Ibom State, Nigeria are facing culture's conflict between typical Akwa Ibom culture and the spread of the Western culture into the interior parts of the state. The most apprehensive of this scenario is the stand taken my traditional rulers considered to be community elders and custodians of traditional laws, norms and social order. As noted by Ngwama (2014), Nigerians today mortgaged their culture of respect, love for human lives, hard work, friendliness and receptiveness to strangers in exchange of the Western culture and ostentatious orientation. According to him (Ngwama), these have given birth to the modern crime and social evil destroying the core value of our society. Against this back drop, this paper seeks to examine the roles of some traditional rulers in complicating social order in some rural areas in Akwa Ibom State Nigeria.

\section{Theoretical Framework}

The researchers adopted Ethnomethodology by Harold Garfinkel (cited in Wallace and Wolf, 1998). According to the theory, people or members of a given society make sense of their social world by invoking their actions and interpret such behaviour with their created meaning. The theory further postulate that the origin of norms and values is not primary of interest, instead their interest is in the process by which human beings interact and prove to each other that they are following norms and values (Wallace and Wolf, 1998). The traditional rulers being the custodians of customs, norms and traditions, have developed new behaviours which depict shift from the cultural context of the people. In their new behaviours, they have interpreted their actions and dragged their created meaning to their new actions as measures taken by the headships of the community toward attaining the norms and values of the 
community. The reactions to these new behaviours or actions by the people, as mediums to attaining reciprocating norms and values, have brought about disruption of social order.

\section{Methods}

The study was designed as a qualitative investigation of the roles of traditional rulers in complicating social order in rural communities in Akwa Ibom State. The study area comprised of Ikot Annang and Ikot Abasi in Onna and Ikot Abasi Local Government Area respectively. The study areas were purposively chosen due to the prevalence nature of unrest between the community leadership and community members especially between community elders and the youths during the time at which this study was under taken. Simple random sampling technique was also used to select study participants which comprised of adult men and women aged between 18 years and above. Since the study was a qualitative with the main aim of gathering information, sample size was not considered, but reaching the point of saturation in the field (Fatterman, 2010).

The study participants were randomly shared among the selected communities. In-depth interviews and participant observation were used to collect data on the subject of the study. Interview guides were semi-structured with open-ended questions. This was deliberately designed to give the participants the liberty to exhaustively share their views on issues as raised by the researchers. Study participants were interviewed by the researchers at homes, shops, and other business premises. From gathered responses, data were codified into key major themes as considered by the researchers from which thematic framework was generated and used for analysis. Coded data was then arranged in accordance to major identified key themes and analyzed accordingly (Bryant and Charmaz, 2007, in Philips, Ononokpono and Udofia, 2016).

\section{Thematic Analysis of Findings \\ Community interest}

Where the interest of the people at community level is put aside by the community elders, social order is distorted as chaos may set into the social structure of the community by different parties in an attempt to either restore community interest in the administration of the community or fight for their respective interests. Majority of the study participants, in their accounts agreed that the greatest challenge facing their community is the betrayal of trust through sabotage of community interest by the elders who were supposed to defend the interest of the people and the entire community.

Our elders seem to have lost their respects because of selfishness. Some of them only care about their immediate families and they have been projecting their selfish interest over the general 
interest of the community, they have been taking what supposed to be for the community to their families and they expect us to be loyal. How can a village head deny us our right by not telling us the truth about compensations, but took all his household and had to called his son that lives outside the community to come and stand for a portion land for compensation when the rightful owners of these lands are in this community and they knew nothing about it.

Traditional leadership in the South-East and South-South region of Nigeria is a republican structure of leadership aided by other age-group organizations especially youths as stated by Fadipe (1970) in Osakede and Ijimakinwa (2015). The nature and leadership style of the community elders is bound to affect the responses of these supported groups and organizations. And in some cases, these traditional rulers used black politicking to manipulate the youths for their selfish interest without the knowledge of these used youths (Peters, Usoro and Bassey, 2018). Where there is knowledge or discovery of such unexpected roles by the elders, the opportunity for disruption of social order seem to be inevitably created for the youths. Most of the study participants for the study areas agreed that community youths ceased such opportunities to exploit community resources, build various forms of oppositions against community leadership and in some cases, engage in modern day crimes.

One of the male participants from Ikot Abasi in his narratives accounted that;

As youths, we were like police in the community; we worked to maintain law and order in the community. We worked for our community leaders and made sure that everybody lived in peace in our community until we discovered that the elder were using us for their selfish gains instead of the community interest. The worst was when the government came to pay compensation for some portions of lands that belong to us. Some elders conspired with the village head to do away with a large part of the money. When we discovered it, we had to see how to fight for our right every time and everywhere because we can no longer trust our elders.

Gathered information showed that social order within the social structure of some rural areas as recorded from the study areas have been disrupted due to the high level of selfishness on the part of some community elders. The reactions to this development from different segments of these rural communities spelled social resistance within the structure of the community. This social resistance varies from one rural community to another and from one group to another. It was observed by the researchers that the kind and degree of resistance exhibited by the women was different from that of the 
youths, and that of some men who are not part of the leadership caucus of their community.

Most of the interviewed women from the study areas showed different degree of displeasure on the level of betrayal of community interest by the community leaders. Some women claimed to have boycott the community women meetings and have made sure that such does not run as smoothly as suppose even though some women who benefit from the community elders' system are struggling to hold irregular meetings.

One of the female participants from Ikot Annang in her narratives stated that;

Some people think that we are not from this community or our husbands are strangers. But such things will never work here because some of us our parents are from this community therefore, nobody should think that he or she can eat what belong to us always and all the time. we are fade up with lies and pretence of some people in this community, people who were to uphold the truths and lead us without partiality, but what we have today is that all they care about is their families and relatives. What kind of leadership is that? The compensations that are to be paid to us, you will see that not up to 10 people will benefit from it apart from their family members. As for the women meetings we no longer attend and we are mobilizing women not to be part of it until we see changes.

The traditional rulers are shouldered with the responsibility of solving the people's problems, establishing peace and order in the rural areas (Achebe, 2017). Where the part of the social structure in a given rural community that is trusted with security of lives and properties, are neglecting their responsibilities, the hope for order and fair treatment to all in such community is a delusion. Gathered data showed that most of community members have thrown away their hope of having a structure that benefits everybody. Thence, they do not care about participating in community activities, keeping or obey the instructions of the community leaders, and respecting some customs and traditions anymore. Some of the study participants in Ikot Abasi agreed that the youths are becoming more engage in community affairs due to lack consistency on the part of the elders in community activities that benefits the generality of the people. The struggles for supremacy between the community elders and the youths have poised serious challenge for attainment and maintenance of social order.

One of the male participants from Ikot Abasi community narrated that; You see, when you trust some elders with responsibilities to defend protect and serve the interest of everybody, and you later discover that they are enriching themselves because they think 
that they are more exposed that everybody, then you are left with no other choice than to protest and show your anger. Some of them will cooperate with outsiders to rob their very own people therefore, in such cases you have no other choice than to rise up and fight to save your future and the future of the your children. Here, we as youths must see and witness what is going on our behalf else, it cannot work, unless very few persons who can talk to us want to deal with us normally.

Researchers, from collected data were able to discover conflict of interests in the some rural communities between the traditional rulers and community members have disrupt social order in these rural areas. This conflict of interests arose from the act of placing selfish interest over community interest on the path of the community elders. By this, the functionality of the social structure is hindered as many parts like women, youths and the aggrieved men worked to the dysfunction of the whole system. The flow of order from the leadership to the members are fading away in these communities, and in some cases as gathered by the researchers, some parts occasionally put up conflicting issues to disturb the leadership group as a means of showing their rights and presence in the community.

These findings are in line with Malinowski (1948) cited in Ayayi (2011). Malinowski asserted that an institution could not be said to be functional except it fulfils some basic needs of its members and that social solidarity is the end product of such social institutions that can be regarded as functional. Traditional rulers are expected to co-operate with different levels of governments and its agencies to identify the needs of their communities and offer useful inputs in the processes involved in service delivery at the grassroot (Peters, Usoro and Bassey, 2018). Community interest is a key responsibility of the traditional rulers due to the expected roles of the traditional leadership stools.

\section{Community Funds}

It was gathered by the researchers that when community funds are mismanaged or diverted for inappropriately expenditure, the people who claim right of ownership and right to details of expenditure of the community funds usually staged different kinds of protest to demand for accountability from the respective offices. These protests have certain degrees of disruption of social order, since it is certain that the presence of conflict does not enhance easy and smooth functionality of the entire system. Majority of the study participants established that mismanagement and embezzlement of community funds are other major causes of internal conflicts between the leadership of their communities and the citizens.

One of the male study participants from Ikot Annang community narrated that: 
Out of selfishness and greediness by some elders in this community there is no accountability of any kind in respect to the community money. We cannot listen to leaders who do not care about the community unless it has to go into their pockets. Like the compensation we are expecting, we cannot allow the leadership to collect it on behalf of the community else we will not see the money. The government will come and take our farm lands like that simply because the village head and some elders will connive together and do away with the money.

Atkinson (2018) posits that most communal poverty is caused not by a failure of production but by a failure in the circulation of money. This position better explains the status of most rural areas in Nigeria. Poverty is a visible characteristic of most rural areas in Akwa Ibom State, and communal poverty in such rural settings needs communal efforts toward alleviation of the social endemic problem. When the poor rural citizens place hope on the shared income, and this shared income is diverted by selected few elders of the community, the rural populace feel rob and deserted by their very royal fathers who by virtues of traditional offices are supposed to make available, provisions of money generated for the community or as allocated to each persons like in the case of some paid compensations by government and other organisations. As gathered by the researchers, frustration resulting from high level of poverty in these communities propels the youth groups, women and aggrieved men to usually come together in some forms of anti-social actions which in some cases caused anarchy within the communities.

Some of the participants attested to the fact that they do not know anything about community funds even though they know that there have been generated funds, donations, grants from organizations, and compensations to the community. It was observed that though there is community purse control by the treasurer of each of these communities, most of the citizens do not have any idea of what goes on with the purse and the money in it. Resultant effects have remained; the bridge of peaceful co-existence and social order within the ranks and relations in the rural areas.

One of the female study participants from Ikot Abasi in her narratives explained that;

We only hear of money, we see people come to collect money from us, we see government and organizations' officials come and give money, we see people come to pay compensations, and we see some politicians come and give money for community projects, but we never hear or know what happen to the money. But after a while we will see the money in the lives of few people and their family members. We have even stopped contributing; in fact we are now fighting for our own share 
because we have been cheated for so long by this few elders and some youth's leaders. If they don't give us our own share, we show them that we are part and parcel of this community. I thank God some youths are arisen for their rights now, so that no few persons no matter your throne can take us for granted.

Orrell and Chlupatý (2016) posit that, of all human inventions, money must be the most deceptively powerful. The power of money as explained in "Evolution of Money" reveals how powerful this invention is and the extent to which this man's creation has control its creator. According to Orrell and Chlupatý (2016), money helped spark the development of writing and the organization of the first city-states, yet it has been the cause of epic bloodlust and the focus of scientific geniuses. Money arouses overpowering emotions but also a kind of detachment. Money has the nuclear power to make or destroy nations. We revere it but also see it as corrupting, even evil, yet our economic theories treat it as a mere tool for exchange and accounting, nothing special in itself.

With the force of individualism which has eaten deep into the degree of communalism known and practiced by most rural areas in Nigeria, the combination of the power of money and force of individualism are creating a changing form of social order which affect the culture of the people and their traditions. This observation by the researchers implies that there exists a shift in the social structure of these rural communities from shared behaviours to individual behaviours. This shift creates opportunity for the traditional rulers to divert community funds to satisfy their selfish desires. Majority of the study participants agreed that community funds have been diverted by the community elders to satisfy their selfish aspirations without concern for the rural populace under their care and leadership.

One of the male participants from Ikot Annang narrated that;

Our community leaders are fun of using community money without accounting for it. We are not against them using the money, but the problem is that they used all the money to live fine at the expense of other members of the community as if we are not there, and as if we do not know anything about our money, or the money that supposed to be our community money. The painful part is that they eat your our money and if you have any case, they still want you to pay hugely before the can attain to your case, is that not exploitation of the people by their rulers?

Gathered data by the researchers show that management of community funds is a complex responsibility of the traditional institutions in the $21^{\text {st }}$ century. This is because; the general shift to capitalism which gives rise to individualism has found its root in what was communal structure in the traditional society. The existing structural shift has deeply affected the relationship pattern between the traditional rulers and their subjects. A key area of the effects is the undermined of community interest by individual interest on the path of the community 
elders in fund management. Responding to this by the other parties has rendered social order in these rural communities a cracking wish among the people.

These findings are in line with to Achebe (2017). Achebe posits that the traditional rulers are supposed to unite in the wars against the common enemies of disease, poverty, ignorance, corruption, crime, drug addiction, armed insurgency, impunity in public office, youth delinquency, etc. and they have become development catalysts and agents for mobilisation for policy implementation, monitoring, and review of policy options. They also focus on peace building and reconciliation, youth empowerment, infrastructural development, crime eradication, and the preservation of our sense of community in the face of the inevitable forces of urbanisation. If these words of Achebe (2017) are not on some selected traditional rulers in Nigeria, but the characteristics of all the traditional rulers in Nigeria especially in some rural areas, the hope of some rural dwellers will see realization, and there will be reduction in rural-urban migration. There is no doubt that for traditional institutions to achieve afore mentioned tasks as outlined by Achebe (2017), there have to be a proper and efficient management of community funds.

\section{Traditions and Traditional Power}

Traditional stool was known to be inherited from forefathers without political elections and possession last for a life time. The traditional phase of the African society seems to have faded away especially in some rural areas in Akwa Ibom State, Nigeria. The challenge to uphold the existence of the traditional stools and African traditions is a complex situation as scenarios within the rural areas are poising many questions. Scientifically, the researchers gathered that there is a big shift from African traditions in the rural areas of Akwa Ibom State to the western traditions. This alteration is on a growing dimension within the rural setting facing a multifaceted competition between the rise of western traditions convey by the traditional authorities and the rural people who are rooted in African traditions. The outcome of this rivalry as gathered by the researchers are neglect of traditional codes of conduct, adoption of westernize culture over Akwa Ibom culture, abuse of traditional stools which accorded the traditional power, and loss of social stability and consensus.

Majority of the study participants complained of the role of the traditional rulers in their communities in leading a symmetrical competition between foreign traditions and indigenous traditions. They gave narrative accounts of how indigenous traditions have been abandoned and subverted by the elders. Other accounts gathered by the researchers were abuses of traditional power to satisfy selfish aspirations over community interest, and conflicts these have brought to the community.

One of the male study participants from Ikot Abasi stated; 
We have to follow them and build the kind of community they want us to build. If they want to live like people who come from America and eat money well well, we must also eat the money and also live like them for peace to reign because the wealth of this land belongs to all of us.

Adoption of western culture over Akwa Ibom culture by the leaders of the communities make the people felt a certain degree of unfaithfulness on the path of the traditional rulers, and this has raised a bar for some modern crimes within the community.

One of the female participants from Ikot Abasi narrated that;

Sometimes we hear from our youths that our rulers are misbehaving, doing things we never heard of in the days of my fathers. Sometimes we witness how serious cases are treated in manners of levity as if such cases were not treated with high sanctions in the past. They don't want to follow the traditions of their fathers anymore. Because of this, some of these young people have ceased the opportunity to live anyhow. Our laws have been bent to favour some acts and I don't if we will have good days again.

A male participant from Ikot Annang has this to say;

Abuse of traditional power is a regular thing here so we know that our leader can misbehave at any time especially if it has to do with money and some items that have to support the house. Elders do not know what it is to respect office or one's self here. Everybody struggle for things when we hear about it because if you wait, they will not give you.

Another female participant from Ikot Annnag has this to say;

Our elder are self-centred, they don't follow any tradition. I don't think that those who lead us in this community know anything about our traditions. The only tradition they know if when they want to share money and other things, they claimed that it is traditionally right to give them the largest portion as leaders.

Information gathered by the researchers indicates that the traditional institutions have shifted from indigenous traditions to foreign traditions. This observations by the researchers confirm the position of Ngwama (2014) which states that, Nigerians today mortgaged their culture of respect, love for human lives, hard work, friendliness and receptiveness to strangers in exchange of the Western culture and ostentatious orientation, and these have given birth to the modern crimes and social evils destroying the core values of our society. 


\section{Discussion}

Three major themes emerged from narratives of the study participants and were considered by the researchers to analyse the roles of custodians of customs and traditions in complicating social order within the pretext of carrying out expected roles ascribed to the traditional stools in Ikot Annang and Ikot Abasi communities in Akwa Ibom State. These themes are; community interest, community fund, and traditions and traditional power.

According to Émile Durkheim social order arose out of the shared beliefs, values, norms and practices that a group of people holds in common (Cole, 2018). This postulation explains the characteristics of traditional society as explained by Durkheim. The shared beliefs, values, norms and other cultural practices are uphold, interpreted, enforced and transmit through generations by the traditional authority ascribed to traditional stools (Peters, Usoro and Bassey 2018; Itodo and Onodugo, 2016; Osakede and Ijimdinka, 2015; Ayuk, Owan and Uyang, 2013 and Fatile and Adejuwon, 2010). African societies are structured in communal beliefs system. This shared system gives rise to social order. In other words, it is a theory of social order that puts culture at the forefront (Cole, 2018).

Traditional leaders played the role of upholding the culture, tradition, norms and values in their domains (Peters, Usoro and Bassey, 2018). Ayuk, Owan and Uyang (2013) posit that without written or documented laws to guide conducts as observed by the western societies, African traditional societies had various channels traditionally through which societies controlled crime and maintained social order. This includes the elders' councils, chiefs, village heads etc, whose functions was the interpretation of the code of conduct and behaviour of the subsisting community as passed down from generations to generation. The core values of the traditional institutions were code of conducts (traditions) which were the power (traditional power) of the society. Every aspect of life was directed by the interpretations of the codes. These codes were sacred and were preserved by the traditional rulers who are custodians of traditional codes, and passed it from generation to generations. Traditional societies in Akwa Ibom State are traditionally governed by the traditional stools which convey traditional authority, and the subjects pay loyalty, and respect to the thrones. Traditional institutions exist across Nigeria with each ethnic region structuring their society in accordance to their culture (Osakede and Ijimdinka, 2015). Same is to be mentioned of Ikot Annang and Ikot Abasi communities in Akwa Ibom State. Findings of the study show that there exist cultural alterations in the social structure of Ikot Annang and Ikot Abasi communities which affect the shared belief of the rural people.

Community interest is the resultant state of collective conscience. Analysed data show that traditional rulers in Ikot Annang and Ikot Abasi communities sabotaged the community interest for their selfish interest. This was discovered to be the greatest challenge facing these communities. Another 
variable discovered to be poising challenge to social order among the people was mismanagement of community fund by the community elders. Most of the study participants agreed that their community elders use community funds for their personal affairs at the expense of their subjects.

Though traditions, African societies were able to controlled crime and maintained social order (Ayuk, Owan and Uyang, 2013). Abandonment of traditions and abuse of traditional power were discovered by the researchers to contribute to conflict within the social structure of the study areas. Contact with western education and western life were found to be responsible for the abandonment of the culture of the people for the western culture. Since social order is convey in the cultural practices determine by the traditional code as interpreted by the elders, the neglect accorded traditions and customs of the place by the royal fathers in these communities disrupt social order within the social structure of these communities.

\section{Conclusion and Recommendation}

The paper examined the role of traditional institutions in conflicting social order in the rural communities in Akwa Ibom State, Nigeria. Community elders who are custodians of traditions, customs and other elements of culture are found to have shifted from what was the status quo of the traditional communities to the influence of the western culture. As explained by ethnomethodology, traditional rulers in these communities have chosen new behaviours as new medium through which norm and values of their communities can be reached thereby creating a new society for the people. This new society is facing the fading of indigenous traditions and culture thereby, creating a society where people abandoned core values and respect for human traditional stools.

To create and maintain social order in our societies today, traditional stools for both royal elders and youth groups should be ascribed rites of passage that emphasize upholding societal core values, traditional codes, enforcement of norms and morals that depict our heritage as true Nigerians and Africans. There should be policy formulation, which will stipulate the duties of traditional rulers in a legal dimension. This will create provisions for defaulters of such to be tried in the court of law, and if found wanting, should be called back, and his certificate withdrawn. This will bring sanity into the conducts and life style of traditional rulers in Nigeria.

\section{References}

Achebe, N. (2017) The traditional institution in modern Nigeria. The Guardian. https://guardian.ng/opinion/the-traditional-institution-in-modern-nigeria

Atkinson, P. (2018) How Money Influence Society. Retrieved [23/9/2018] online from https://www.quora.com/How-does-money-influence-society. 
Ayayi, A. (2011) Assessment of Traditional Institutions and Socio Economic Development of Benin City. Munich, GRIN Verlag, https://www.grin.com/document/197754

Ayuk, A.A., Owan, E.J. \& Uyang, F.A. (2013) Traditional Methods of Crime Control and Community Security in Odukpani Local Government Area of Cross River State-Nigeria. IOSR Journal of Humanities and Social Science (IOSR - JHSS), 14(5): 61-66. www.Iosrjournals.org.

Cole, N.L. (2018) What is Social Order. Overview and Theoretical Approaches. Retrieved [23/9/2018] online from https://www.thoughtco-.com/socialorder-definition-4138213.

Durkheim, E. (1947) The Division of Labour in Society. New York: The Free Press.

Fatile, J.O. (2010) Boundary Disputes \& Communal Conflict Resolutions. The role of traditional rule. Lagos: Ziklay consult workshop.

Fatile, J.O. and Adejuwon, D.K. (2010) Conflict \& Dispute Resolution in trade unionism in Nigeria. A Journal of Public Policy and Administration Studies, 6(3): 40-52.

Fetterman, D.M. (2010) Ethnography: Step-by-Step. SAGE Publication, Inc. California.

Itodo, S.M. \& Onodugo, I.C. (2016) Traditional Rulers and Democratic Consolidation in Nigeria. Social Sciences Journal of Policy Review and Development Strategiesm, 2(1).

Ngwama, J.C. (2014) Kidnapping in Nigeria: An emerging social crime and the implications for the labour market. International Journal of Humanities and Social Science, 4(1): 133-145.

Orrell, D. and Chlupatý, R. (2016) The Evolution of Money. Columbia University Press.

Osakede, K.O. \& Ijimakinwa, S.O. (2015) Traditional Institution and the Modern Dayministration of Nigeria: Issues and Prospects. Journal of Research and Development (RnD), 2(9).

Peters, M.I., Usoro, N.A. \& Bassey, A.E. (2018) Traditional Institutions and Underdevelopment of Some Rural Communities in Akwa Ibom State, Nigeria. A paper presented at Pan-African Anthropological Association (PAAA) International Conference 15th to 17th of August, 2018 at University of Calabar, Cross River State, Nigeria.

Petkovi, J. (2007) Traditional Values and Modernization Challenges in Forming Urban and Rural Culture. Series: Philosophy, Sociology and Psychology. 6(1): 23-39.

Phillips, B.S., Ononokpono, D.N. \& Udofia, N.W. (2016) Complicating Causality: Patient and Professional Perspectives on Obstetric Fistula in Nigeria. Culture, Health and Sexuality. International Journal for Research, Intervention and Care. 
126 The Nigerian Journal of Sociology and Anthropology Vol. 17 no. 2

Wallace, R.A. \& Wolf, A. (1998) Contemporary Sociological Theory; Expanding the Classical Tradition. Prentice-Hall, New Jersey. 